\title{
Do we have what is needed to change everything?
}

\section{A survey of Finnish software businesses on labour shortage and its potential impacts}

\author{
Sonja M. Hyrynsalmi ${ }^{1}$, Minna M. Rantanen ${ }^{2}$, and Sami Hyrynsalmi ${ }^{3}$ \\ 1 University of Turku, Department of Future Technologies, Turku, Finland \\ smnyla@utu.fi \\ 2 University of Turku, Turku School of Economics, Turku, Finland \\ minna.m.rantanen@utu.fi \\ 3 Tampere University of Technology, Pervasive Computing, Pori, Finland \\ sami.hyrynsalmi@tut.fi
}

\begin{abstract}
The fourth industrial revolution is expected to bring major changes both in society as well as in the modern industry. Naturally, it will also shake the labour market - however, not only by replacing blue collar duties by robots, but also by renewing the set of skills and competencies needed in new kinds of work duties. In this study, we use a data $(n=160)$ from a survey to the Finnish software businesses to evaluate how software companies perceive the labour shortage and its implications in the verge of the new industrial revolution. The results show that already now there are signs that the labour shortage might harm the growth and innovations in the ICT field. This study presents the results from the survey and discusses whether there are enough competent resources to support the industrial revolution.
\end{abstract}

Keywords: Fourth industrial revolution, skills, competence, software business

\section{Introduction}

Nowadays, a common interpretation is that we are right now on the edge of the fourth industrial revolution. New technologies and innovations are arising from areas such as robotics, artificial intelligence, machine learning, nanotechnology and biotechnology. Together, they are forming new kinds of possibilities for humankind. $[1,2]$

The history already identifies three different industrial revolutions. The first industrial revolution was characterised by the industry's utilisation of steam power. The second industrial revolution was full of innovations powered by electricity and the third industrial revolution was the time of digitalisation. Now, the fourth industrial revolution is seen as a fusion of physical, digital and life-science technologies. [3] 
However, the differentiating factor between previous industrial revolutions and the current one is the speed of current breakthroughs. [4] It has been evaluated, that the fourth industrial revolution is evolving at an exponential pace rather than a linear. It is also notable, that the new revolution is disrupting almost all sectors of the modern industry in every country at the same time. [1]

Major technological innovations in all industrial revolutions have been shown to be accompanied by large-scale transformations in the labour market $[5,6]$. In addition, it is also said that all of them has always been a race between education and technology [7]. This ongoing technological change has already shown that Robotic Process Automation (RPA) made computing more affordable and at the same time educated software workers with cognitive problem-solving and project skills are becoming highly recognised [8].

In a recent report, the World Economic Forum [9] points out that the fourth industrial revolution will influence the skill sets required in both old and new occupations. Those new skills and competences will change in most industries, and most notably in the field of information and communication technology (ICT). It may also affect male and female workers differently, and transform the dynamics of the industry gender gap.

As an early signal for the new industrial revolution, the need for new skills and competences has arisen among software companies. Already now, various ICT specialist jobs have been among the most dynamic occupations in the past few years [10]. Furtermore, several forecasts have suggested that the demand for ICT professionals with different skills and competences will continue grow, and it is expected that the growth rate, in a shortcoming future, is likely to be even faster. In 2014, ICT specialists accounted for $3.6 \%$ of all workers in Organisation for Economic Cooperation and Development (OECD) countries [11], and in the European Union (EU), nearly 8 million persons were employed as ICT experts, representing $3.7 \%$ of total employment in 2014 [12]. According to, e.g., World Economic Forum, ICT specialist open vacancies are going to be harder to fill and the fourth industrial revolution is also changing the skills that employers need and shortening the applicability time of employees' existing skill sets in the process. [9]

The ICT industry has an important role to play in creating the foundation for the new business from the fourth industrial revolution. The lack of ICT labour is not only the problem of software industry, because ICT is nowadays crossdisciplinary - more new talents and innovators are needed in the all industrial sectors. If there is not enough labour for the new business, there will be a shortage of new innovations and new jobs. [12] Thus, it is important to acknowledge how labour shortage could impact on outcome of the fourth industrial revolution.

This study does not focus on the often-seen argument for robots 'stealing' people jobs. On the contrary, this study focuses how demands of the fourth industrial revolution are changing the software industry jobs and how companies, universities and ICT professionals can cope with ever-increasing and fast change. On the other way around, this study concern humans, their skills and position in an ever-changing environment. 
In this study, we focus on the following research question:

RQ How do software companies perceive labour shortage and how does it influence into companies?

To answer the presented question, we use a survey of Finnish software companies regarding the labour shortage in ICT industry. In total, the survey received 160 responses (ie., $\mathrm{n}=160$ ). We are interested to study is there really a lack of competence in the field of software industry.

The remaining of this work is structured as follows. Section 2 shortly discusses related work while Section 3 presents the acquisition of empirical material for this study. Section 4 presents the results and it is followed by the discussion of implications as well as limitations in Section 5. The last section concludes the study.

\section{Background}

Industrial revolutions have had different kinds of needs from the workforce. First, steam power and factories took over artisan handwork and after that, machines and more efficient manufacturing chains changed demand for the workforce at the second industrial revolution. The third industrial revolution, the so called digital revolution, generated demand for a new kind of white-collar, the nonproduction, workers. $[3,6]$

In the academic research field the skill-biased technical change (also known as unskilled labor-saving) has been at the eye of debate years. [13, 14] According to Goldin and Katz [7], skill-biased technical change was a characteristic for the twentieth century. The demand for skilled labour, despite unskilled labour, growth in every decade of twentieth century [15]. In software business 'soft skills', such as self-direction, information-processing, problem-solving and communication, become more important [16].

'The Future of Jobs' -survey by the World Economic Forum shows that there is a growing demand on technical and social skills as well as cognitive abilities in the field of information and communication technology. According to the report, the main job families which are going to have difficulties of recruitment are database and network professionals, software and applications developers and analysts, electrotechnology engineers and architects and surveyors. [9]

The fourth industrial revolution will also shake not only the jobs and required skills but also the business field of information and communication technology. For instance, a study by Roland Berger Strategy Consultant [17], commissioned by the Federation of German Industries (BDI), shows that Europe has a great potential at the field of new business opportunities in ICT. They suggest that the new digital transformation of the industries could add as much as EUR 1.25 trillion to the overall Europe's industrial value creation by 2025; however, if Europe misses the change to the new markets, that value will diminish it by EUR 605 billion 
European Union has also investigated the business potential in ICT industry and estimated that new business from digital economy could contribute EUR 415 billion per year to the EU economy. Furthermore, this kind of development would create hundreds of thousands new jobs in the EU. [18]. However, for fulfilling the new business potential, new skills and more labour is needed. Nevertheless, finding the skilled labour is going to be even harder: European Commission [18] has studied that by 2020 there will be 756,000 unfilled vacancies for ICT professionals in the whole economy. The European Union's e-skills report for the year 2020 has predicted that demand for new skills ranges at every skill level, but in the next decades there is going to be growing demand especially for more advanced digital skills. [19]

For instance in Finland, estimations of needed ICT labour varies from 7,000 to 15,000 and the estimated need is growing yearly by 3,800 persons when only 1,100 students graduate from the field of computer science and technology. [20] That is alarming number which fosters debate about Finland losing it opportunity to be one of the world's leading countries in digitalisation. More political focus and actions are demanded from government to the technological education. [21]

Past few years there has been shown strong growth in the Finland software industry and companies really are ready to expand to the international markets. [22,23] That is a good sign because export of ICT industry is already crucial to the Finnish national economy. It is already the second largest industry group after paper and pulp industry and covering $11.4 \%$ of national export yearly. [24]

However, there is a danger that Finland is not using it full potential from fourth industrial revolution. World Economic Forum has stated that Finland is one of the top 5 countries which enjoy a high state of digital advancement while there are signs of a slowing momentum. These top countries (i.e., Finland, Denmark, Norway, Sweden, and Switzerland) are all leading countries in digital technology right now. However, they all face challenges with sustaining growth and reinventing themselves. [25]

Like in all technological competences in every industrial revolution, there will be winners and losers in the fourth industrial revolution. Those countries who will adapt new technologies and skills more agile than others countries are more likely to be winners in this revolution. Furthermore, it is also the race between continentals because the availability of a large talent pool would contribute to make Europe a better place to invest and do business. [26] Luckily, already now the European Union, OECD and the World Economic Forum among other actors have done a lot of strategy implications and cleared pathway to countries really take advance from the fourth industrial revolution.

\section{$3 \quad$ Research process}

The primary data for this study was collected with a questionnaire survey targeted to the owners of Finnish software businesses. The survey was sent via e-mail 
to the member companies of Finnish Software Industry \& Entrepreneurs Association by the association on the requested of Helsingin Sanomat ${ }^{4}$, the largest national newspaper in Finland. The association acts as an advocate of software industry in Finland and a community for software business executives. It promotes growth and internationalisation of the industry. The association has approximately 600-700 members.

The survey's questions considered labour shortage in software business. The survey has two parts: First, the future development of the responding company were asked. Second, questions regarding the impact of labour shortage as well as the language used in the workplace and the percentage of non-Finnish workers were inquered. Overall, the survey consisted of 11 questions, varying from openended to multiple choice and scale questions using Likert scale. The survey was done in Finnish.

The survey was conducted in the beginning of fall 2017. In total, 160 top level managers answered to the questionnaire. Thus, the approximate response rate for the survey is around $23-26 \%$. The respondents are from different areas of software business, ranging from consultancy to product and service business. A clear majority of the respondents' companies belong to business-to-business markets.

For the scale questions, the averages and median values were calculated. An equal interest is on the open-ended questions. Those questions were analysed by using qualitative approach. In the analysis, we followed the general guidelines given by Robinson et al. [27].

Each answer was analysed and coded by a researcher. The codes were not predefined; on the contrary, they were created based on the repeating themes in the answers. After all answers were coded, the codes were reviewed and similar codes were combined. All answers given by the respondents were written in Finnish. Therefore, all quotations presented in this study are translated by the researchers.

\section{Results}

In the following, we will first present the results of quantitative questions. It is followed by the analysis of responses to the open-ended questions.

\subsection{Quantitative responses}

In total, 160 answers were gathered to the survey. In the first part of the survey, companies' expectations for the near future were asked. Overall, the respondents are feeling optimistic towards the future: Only $3.1 \%$ of the respondents predicted that the turnover would decrease in the forthcoming six months while $90.0 \%$ believed it would grow either moderately or considerably. However, responding

\footnotetext{
${ }^{4}$ Kempas, K. "Koodareita haetaan yhä useammin ulkomailta, koska Suomessa ei riitä osaajia - jotkut yritykset haluavat olla 'sataprosenttisesti suomalaisia"'. Helsingin Sanomat, October 5th, 2017.
} 
Table 1. The percentage of foreign workers in responding companies. $(n=160)$

\begin{tabular}{rr}
\hline Foreign workers Share of answers \\
\hline None & $36.9 \%$ \\
$1-20 \%$ & $41.9 \%$ \\
$21-40 \%$ & $14.4 \%$ \\
$41-60 \%$ & $4.4 \%$ \\
$61-80 \%$ & $0.6 \%$ \\
$81-100 \%$ & $1.0 \%$ \\
\hline
\end{tabular}

companies were more critical regarding development of their profitability. As many as $6.3 \%$ evaluated that the profitability will worsen a little during the next six months, $31.9 \%$ claimed it will stay same. Again, a majority of $43.8 \%$ claimed that the profitability will grow better a little and $18.1 \%$ of the respondents answered that it will grow remarkably.

Altogether, these results reveal that a clear majority of the companies forecast remarkable growth in near future. A reasonable share of companies believed that both turnover $(34.4 \%)$ and profitability $(18.1 \%)$ will increase significantly during the next six months. These can be read as weak signals of growing economy. Moving forward to need of new staff, only two companies $(1.3 \%)$ believes that the total number of staff in the company is likely to decrease. At the same time, approximately one fourth $(23.8 \%)$ is not expecting any changes in six months. However, more than a half of respondents $(56.9 \%)$ are willingly and expecting to recruit new personnel. Furthermore, from all responding companies, $29(18.1 \%)$ are interest to recruit several new people and increase the size of personnel significantly.

Also the working language of the companies was asked. From all respondents, $78.8 \%$ announced using either only English or some combination of English, Finnish and Swedish. Only $21.3 \%$ revealed using only Finnish as working language. In addition, the percentage of foreign workers were inquired and the results are shown in Table 1. While more than one third of responding companies does not have foreign staff at all, $41.9 \%$ of companies have from 1 to 20 percentage of workers from abroad.

In the second part of the survey, companies were inquired opinions regarding the labour shortage. In a Likert scale question, an opinion was asked on the statement that there are not enough information and communication technology labour in Finland. As shown in Figure 1 (a), $38.8 \%$ respondents are confident that there is not enough information and communication competence in Finland for their need and $28.8 \%$ respondents are positively sure about that. The average value for the question is 3.79 and median value is 4 .

In the second Likert scale question, an opinion was asked on the statement that the lack of information and communication competent labour is influencing to a company's growth potential. Figure 1 (b) shows that $30.6 \%$ of the 

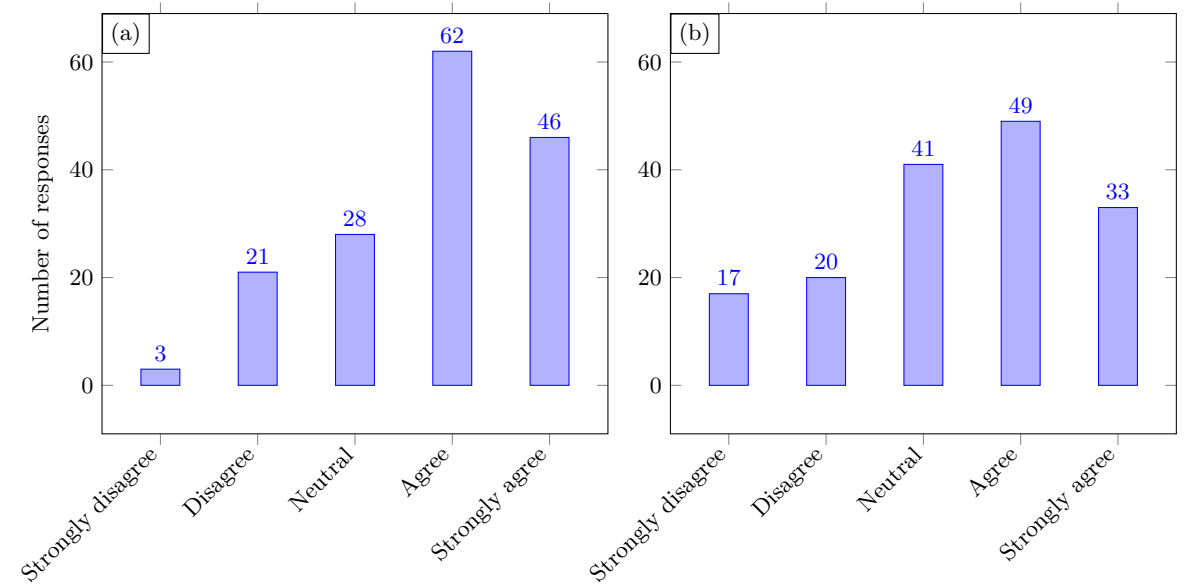

Fig. 1. Distribution of answers for (a) 'There are not enough information and communication technology labour in Finland', and (b) 'Lack of information and communication competent labour is influencing to a company's growth potential' $(\mathrm{n}=160)$.

respondents agrees that lack of competence is effecting their company's growth potential and $20.6 \%$ strongly agrees with the statement. The average value of the responses is 3.38 and median value is 4 .

In addition, it was whether the company is looking for new employees also from abroad or mainly in abroad. From all companies, $42.5 \%$ stated that they are looking new employees mainly from Finland while also $42.5 \%$ stated that they are looking from Finland and abroad. Only $6.9 \%$ of companies stated that they are looking new employees primarily from abroad.

To summarise quantitative responses, the responding companies are seeing the forthcoming future as bright - a clear majority of the respondents were expecting growth in all three aspects: turnover, profitability and size of personnel. From all respondents, $63.2 \%$ have already non-Finnish staff members. Furthermore, the number of companies using English as their working language is higher than the number of companies having foreign staff. Thus, this might be seen as an indication that there are companies that would be able easily to take foreign workers, but have not yet done so. Furthermore, nearly half of the companies were looking for new candidates also from abroad while only a small portion was looking only candidates from abroad.

Finally, the results also show that the companies' have identified labour shortage problem. As reported by Figure 1, there seems to be a lack of competent labour in Finland. Furthermore, a majority of companies see the lack of competent workforce - whether from Finland or from abroad - as a drag for the growth. 


\subsection{Qualitative responses}

Out of the all, 90 respondents $(56.3 \%)$ answered to the open-ended question how labour shortage affects your company. In total, there are nearly 3,000 words written as answers to the question. The lengths of the answers varied from a few dozens of words to a hundred. As described in Section 3, all answers were coded. The following observations were made on the basis of the finalised coding.

First, there is a clear division between whether there are labour shortage and does it influence on the companies growth strategy. One answer could not be classified in either group. A clear majority (65 companies, $73 \%$ ) of the respondents believes that there is labour shortage and it has or will have an impact. Still, a bit more than one fifth $(27 \%)$ believes that there are no influence.

In the following, different issues that were repeated in the answers, and thus coded in the analysis, are discussed. The arguments for the negative influence of labour shortage are often based on experienced problems. For example, one respondent states "Recruiting processes are long and require lots our own resources. Our own experts are every now and then overburdened, [...]", thus illustrating the common problems caused by the labour shortage. This quote also emphasises another problem often occurring in the answers: the recruiting processes are long and arduous. Furthermore, there are both respondents that say the recruitment is hard in the capital area as well as those stating that recruitment is hard outside of the capital area.

Another aspect frequently occurring in the answers are the effects caused by the labour shortage. For example, a respondent stated that "We cannot offer as much services as our clients would need. We cannot get enough competency for the projects, which is the reason why the projects are expensive, slow and risky. [...] The workers are able to survive from the projects, by the hard way, but there are not enough skilled workers who could help to avoid pitfalls or be able to take modern alternatives in the use." Thus, underlining that more competent labour would be able to work more efficiency and be able to learn and utilise the newest tools and frameworks.

In addition, one company told that "Due to the labour shortage of software business, we cannot respond to the demand and we are forced to answer 'nocan-do'. Furthermore, we cannot develop our product to international markets because the domestic demand already uses all of our resources. We could grow remarkably faster if there would be more competent workforce available." Similar reasoning for the influences of the labour shortage were present also in other responses.

On the contrary to aforementioned perceptions, there are roughly two different kinds of answers that disagree with the labour shortage causing problems to the industry. However, only $27 \%$ of the answers did not see the labour shortage influencing to the company's growth. In the first group, the respondents do not see the labour shortage influencing the companies or their growth in any way. For example, one respondent explained that "It [the labour shortage] does not have influence. There are thousands of educated people unemployed in the software field. The problems is that the companies wish to have the top experts 
with a small salary and there is a lack of that kind of workforce in all fields. The special problem in the software field is that knowledge expires mostly in five years."

In the latter group, the respondents do not have had problems caused by the labour shortage either due to the use foreign workforce and offices abroad, or they have not have any problems yet, but are doubtful that in the future there might be. As an example of the former, a respondent stated that "We have recruited foreign workers so there are no influence [of the labour shortage]. It is actually a good thing that there are no Finnish workers anymore so teams' diversity grows naturally." Also, other respondent stated that "No influence, we have found top experts. Today, one arrived in Helsinki from [a city in USA] with his vanload." As an instance of the latter, one of the respondents told that "Currently, there are no labour shortage, the problems are in somewhere else. However, if the problems can be fixed, getting new staff, and possibly the labour shortage, become more relevant issue." Nevertheless, this can be seen as an indication that there are no enough competent workforce available in Finland.

To summarise qualitative results, there are arguments for and against that the labour shortage influences negatively on firms and their growth. However, around three-fourths of the respondent agreed in their open-end answers that the labour shortage influences in their companies. The main themes arisen from the data are (i) the problems in recruiting new staff both in the capital area as well outside the capital area, (ii) the lack of top experts prevents adoption of new tools and frameworks, and (iii) due to the lack of competent labour, companies are not able to grow as fast as they would hope to.

Yet, there are also opposite views and observations that the labour shortage problem does not influence on the growth of the firms. Often the respondents refer to being able to either outsource work to another countries or by hiring foreign staff. However, also companies having foreign workers and actively recruiting those report problems in acquiring new staff.

\section{Discussion}

In the following, we will first discuss the key findings of this survey and their implications. This sections ends with limitations of the study and some proposals for future work.

\subsection{Findings and implications}

This paper sought to study how do Finnish software companies perceive the labour shortage and whether it has an impact on the companies or not. Based on the survey, it seems that a majority of software companies have already experienced problems in recruiting competent workforce. Furthermore, several respondent explained how the lack of competent workforce influence to the quality of products, project timetables, and even in the potential growth of the company. These lead to the question presented in the title of this study: Do 
we actually have what is needed to change everything with the fourth industrial revolution? Otherwise, the fourth industrial revolution, that is expected to be a major disruption in several industrial fields, could become only a disrupted disruption.

In this study, we have noted that right kind of skills in the software industry are already hard to find. We also expect that it will become even more harder in the next couple of years. This has a lot to do with national prosperity if there is not enough right kind of workforce, there will be no new business and from that no new jobs. As a result, the society will not be renewed at the same pace than other countries and the whole fourth industrial revolution will not fully implement to that specific country. Thus, this is a matter of national development and should not be left solely on the shoulders of entrepreneurs.

European Union and OECD have, for years, promoted skills strategies. For instance, OECD has developed a comprehensive skills strategy that help countries to analyse their national skill systems and identify its strengths and weaknesses. The strategy helps a country to benchmark itself internationally and develop policies that can transform better skills into better jobs, economic growth and social inclusion. [11] However, it must be noted that strategies alone do not create change - political commitment is needed as well as meaningful development of strategies and actions based on them.

Nevertheless, there is always risk when skill policies are developed based on trends and current task demands [11]. Economic history has shown to us, economies have continued to create enough jobs for their workforce after periods of disruption, However, digital revolution is more difficult to foresee due its unique characteristics. [5].

It is worthy to note, that when we are considering skills, we should not focus only for problems of filling the open vacancies. The new industrial revolution will acquire new skills also from the old workers. Investing in re-skilling current employees will more likely rise more and more common in next few years.

In the fourth digital revolution, the possibilities are likely unlimited. This new revolution will combine the physical, biological and digital worlds - and in the unskilled hands, there is a change that it could bring more harm than good. This is reason why a high educated competence is needed with multidisciplinary skills.

Altogether, the fourth industrial revolution is expected to shake all known industries. Information and communication technology is a a cross-cutting field and therefore the lack of right kind of skills and competences will effect not only for software business but also to the fields of art, life science, economics and others. That is, to be able to change everything, we have to get our focus on the right skills for the new era.

\subsection{Limitations \& future work}

Naturally, this study has certain limitations that should be acknowledged. First, the study is based on a survey sent to the members of the software entrepreneurship association. The association and its members represent only a fraction of 
the whole software industry in Finland; however, the member companies are well-doing companies in Finland and they are represent well the whole industry. However, this might bias the results.

Second, the whole survey was implemented in Finland and the generalisation of results in other western countries is questionable. While Finland shares remarkable similarities with other European and western countries, it is located in the northern end of the Europe and might not be able to lure competent workforce as well as the central European countries.

Nevertheless, this study opens avenues for future research. First, a qualitative survey to both job seekers and companies would reveal more insights on the phenomena. Second, it seems that the governments, such as Finland, need more detailed skills and competency strategy to respond to the changes bring by the fourth industrial revolution. Thirdly, education and re-education in the field of ICT should be studied more in relation to this change.

\section{Conclusion}

This paper surveyed how software businesses in Finland perceive labour shortage. From the 160 responses, a clear majority is stating that the labour shortage will slow down the growth potential. The companies revealed, e.g., that recruiting processes took long time and too much companies resources and it is hard to find competent workforce for senior level positions. Therefore, the companies are not able to grow their business as they would like to.

The title of this study asked whether we have all that is needed to change everything. As the new industrial revolution is expected to have, again, a massive impact on our society and living, the companies thriving the revolution need competent workforce to do so. Based on the results achieved in the empirical inquiry of this study, we have to state that we might not have all that is needed for the change.

\section{Acknowledgements}

The authors wish to thanks Managing Director Rasmus Roiha and Finnish Software Industry \& Entrepreneurs Association for sharing the dataset used in this study.

\section{References}

1. Schwab, K.: The fourth industrial revolution. Foreign Affairs (2018) Accessed January 23, 2018.

2. Hermann, M., Pentek, T., Otto, B.: Design principles for industrie 4.0 scenarios. In: 2016 49th Hawaii International Conference on System Sciences (HICSS). (2016) 3928-3937

3. Katz, L.F., Margo, R.A.: Technical change and the relative demand for skilled labor: The united states in historical perspective. Working Paper 18752, National Bureau of Economic Research (2013) 
4. Frey, C.B., Osborne, M.: Technology at work: The future of innovation and employment. Oxford Martin School and Citi GPS, Oxford, England (2015)

5. OECD: New Markets and New Jobs. Number 255 in OECD Digital Economy Papers. OECD Publishing (2016)

6. Frey, C.B., Osborne, M.A.: The future of employment: How susceptible are jobs to computerisation? Technological Forecasting and Social Change 114 (2017) 254-280

7. Goldin, C., Katz, L.: The race between education and technology. Harvard University Press, Cambridge, Massachusetts (2009)

8. Autor, D.H., Levy, F., Murnane, R.J.: The skill content of recent technological change: An empirical exploration. The Quarterly Journal of Economics 118(4) (2003) 1279-1333

9. World Economic Forum: The Future of Jobs: Employment, Skills and Workforce Strategy for Fourth Industrial Revolution. Global Challenge Insight Report. World Economic Forum, Geneva, Switzerland (2016)

10. Lehner, F., Sundby, M.W.: ICT skills and competencies for SMEs: Results from a structured literature analysis on the individual level. In Harteis, C., ed.: The Impact of Digitalization in the Workplace: An Educational View. Springer International Publishing, Cham (2018) 55-69

11. OECD: Skills for a digital world. Policy brief on the future of work, OECD Publishing, Paris (2016)

12. Eurostat: ICT specialists in employment. Technical report, European Union (2017)

13. Berman, E., Bound, J., Machin, S.: Implications of skill-biased technological change: International evidence. The Quarterly Journal of Economics 113(4) (1998) $1245-1279$

14. Autor, D.H., Katz, L.F., Krueger, A.B.: Computing inequality: Have computers changed the labor market? Technical Report 5956, National Bureau of Economic Research, Cambridge, MA (1997)

15. Falk, M., Biagi, F.: Relative demand for highly skilled workers and use of different ICT technologies. Applied Economics 49(9) (2017) 903-914

16. Spiezia, V.: Jobs and skills in the digital economy. OECD Observer (2016)

17. Roland Berger Strategy Consultants: The digital transformation of industry: How important is it? Who are the winners? What must be done now? A European study commissioned by the Federation of German Industries (BDI) and conducted by Roland Berger Strategy Consultants (2015)

18. European Comission: The Digital Single Market - State of Play. European Union (2017)

19. Berger, T., Frey, C.B.: Digitalization, jobs and convergence in Europe: Strategies for closing the skills gap. Technical report, University of Oxford (2016)

20. Tieto- ja viestinttekniikan ammattilaiset TIVIA ry: Ohjelmisto-osaaminen Suomen talouskasvun ja uudistumisen jarruna - vuonna 2020 Suomesta puuttuu 15000 ohjelmistoammattilaista (2017) Press release.

21. Naumanen, M., Leinonen, A., Lehtoranta, O., Loikkanen, T., Nieminen, M., Pelkonen, A., Pellinen, P., Parkko, J.: Tekbaro 2017. Tekniikan akateemiset TEK, Helsinki, Finland (2017)

22. Luoma, E., Rönkkö, M., Tahvanainen, S.: Finnish software industry survey 2017 (In Finnish Ohjelmistoyrityskartoitus 2017) (2017) Accessed January 23, 2018.

23. Rönkkö, M., Mutanen, O.P., Koivisto, N., Ylitalo, J., Peltonen, J., Touru, A.M., Hyrynsalmi, S., Poikonen, P., Junna, O., Ali-Yrkkö, J., Valtakoski, A., Huang, Y., Kantola, J.: National software industry survey 2008: The finnish software industry in 2007. Technical report, Helsinki University of Technology (2008) 
24. Haaparanta, P., Tamminen, S., Heikkinen, S., Aunesluoma, J., Nilsson Hakkala, K., Kiviluoto, J., Lavikainen, K., Rissanen, A.: 100 vuotta pientä avotaloutta - Suomen ulkomaankaupan kehitys, merkitys ja näkymät. Technical report, Valtioneuvoston selvitys- tutkimustoiminta (2017)

25. Chakravorti, B., Bhalla, A., Chaturvedi, R.S.: 60 countries' digital competitiveness, indexed. Harvard Business Review (2017)

26. Korte, W.B., Hüsing, T., Dashja, E.: High-Tech Leadership Skills for Europe Towards an Agenda for 2020 and beyond. European Communities (2017)

27. Robinson, H., Segal, J., Sharp, H.: Ethnographically-informed empirical studies of software practice. Information and Software Technology 49(6) (2007) 540 - 551 